\title{
Does Impact of Using an Online Learning on Salesmanship Course in The Era Covid 19 Pandemic?
}

\author{
Harti $^{1}$, ${ }^{*}$ Raya Sulistyowati ${ }^{2}$, Tri Sudarwanto ${ }^{3}$, Septyan Budi Cahya ${ }^{4}$, Veni Rafida ${ }^{5}$, Tareq Furas ${ }^{6}$ \\ $1,2,3,4,5$ Universitas Negeri Surabaya, Surabaya, Indonesia, \\ ${ }^{6}$ University Putra Malaysia, Selangor, Malaysia
}

\begin{tabular}{|c|c|}
\hline (A) Check for updates open 0 access cC) & DOI : https://doi.org/10.46245/ijorer.v2i3.114 \\
\hline Sections Info & ABSTRACT \\
\hline 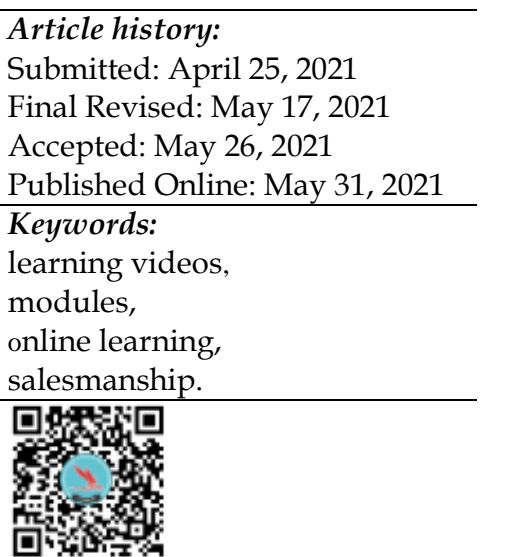 & $\begin{array}{l}\text { This research aims to explore the application of learning salesmanship courses during } \\
\text { the COVID-19 pandemic, where there are social policies and physical distance } \\
\text { conducted by online lectures, while salesmanship courses will be effective if done } \\
\text { with many direct practices. Approved implementation of planning, implementation, } \\
\text { and evaluation of the implementation of online learning with the support of learning } \\
\text { applications such as learning modules and videos. This research was conducted using } \\
\text { descriptive qualitative, discussion, and collect data about responses and submissions of } \\
\text { learning applications consisting of modules and video sales used during the online } \\
\text { learning process. The technique of collecting data is done by collecting, observing, } \\
\text { and questioning. Data were analyzed qualitatively using NVIVO software. The results } \\
\text { showed that learning tools in the form of salesmanship modules and videos received } \\
\text { very high responses, and were effective in fostering student interest in learning, the } \\
\text { results of data analysis showed that with modules and videos made learning } \\
\text { salesmanship easier, especially on the topic of effective selling techniques online at a } \\
\text { pandemic period, very relevant to current needs. }\end{array}$ \\
\hline
\end{tabular}

\section{INTRODUCTION}

Coronavirus Disease (COVID-19) is increasing in Indonesia (Joharudin et al., 2020; Sumarni, 2020). PHEOC of the Ministry of Health on May 29, 2020 accessed via covid19.kemkes.go.id stated that the number of positive cases in Indonesia was 25,773 people and 1,573 people died. This outbreak has an impact on educational factors, this is evidenced by the policy to stop the process of face-to-face learning activities (Muliadi et al., 2021). The Ministry of Education and Culture issued a policy by issuing Circular Number 4 of 2020 concerning Implementation of Education in the Coronavirus Disease (COVID-19) Emergency Period. Two important policies from the circular are schools conducting Distance Learning (PJJ) for students, and canceling the implementation of the National Examination (Atsani, 2020; Pakpahan \& Fitriani, 2020).

Learning is done remotely or via E-Learning. Minister of Education and Culture (Mendikbud) Nadiem Makarim also seeks to build cooperation with various parties that focus on developing an online education system. The application of online learning demands the readiness of various parties, both from education service providers or from students themselves (Susanty, 2020). Online learning is not something new for universities, because many universities have innovated and developed online learning to improve its quality and quality (Hutauruk, 2020).

Salesmanship is a course in the Commerce Education study program that discusses knowledge about products and marketing strategies, knowing and having good relations with customers and being able to form networks with the business world, as well as excellent service and after-sales (Rusly \& Sudarwanto, 2021). In the lecture implementation plan, previously carried out by the method of lecturing, discussion, observation, case studies, presentations, and reflections carried out with a face-to-face 
learning process. This course is one of the courses taught during the COVID-19 pandemic, so that the learning process uses an online distance learning system. This of course will change the planning and implementation that has been made previously. Something that is a challenge in itself for lecturers and students in this change, especially in this subject not only requires deepening of theoretical but also practical material.

Looking at the implementation of the system being carried out because of reasons that were not predicted beforehand, it is necessary to examine how the application of online learning is related to planning, implementation, evaluation and follow-up of the learning carried out, as well as the impacts and constraints in the learning process.

\section{RESEARCH METHOD \\ General Background}

The method used in this research is descriptive qualitative research. This type of descriptive research used is a case study (case study). This method contributes to science by providing up-to-date information, and can help identify factors that are useful for conducting experiments. This method can be used in describing situations that may exist in a particular situation. Qualitative research using a case study research design means that the research is focused on a single phenomenon that is selected and wants to be understood in depth, ignoring other phenomena.

\section{Sample}

This research was obtained through observation and interviews with students and lecturers of the Department of Commerce of the State University of Surabaya in relation to the application of online learning that they do in distance education. Meanwhile, secondary data in this study were obtained from books, encyclopedias, articles, journals, or other writings related to research. Researchers in this study determined research subjects based on the problems studied regarding the application of online learning in the salesmanship course during the COVID-19 pandemic. So the researchers determined the main subjects in this study amounted to 4 people, namely 2 lecturers and 2 students in the salesmanship course.

\section{Instrument and Procedures}

The data collection instruments used in this study were in the form of observation guidelines, questionnaires and interviews. In qualitative research, the observation guideline is only an outline or general points of the activity to be observed. Details of the observed aspects are developed in the field in the process of carrying out observations. The instruments are used to get responses from students in more detail regarding the processes and activities carried out. Where the questionnaire is used here as a complement to the research data, so that the results used are not biased and can be clearer. A questionnaire or questionnaire is a research instrument in the form of a list of questions to obtain information from a number of respondents (the source of which data is taken through a questionnaire), in this study a questionnaire was given to students to find out student responses to the online lecture process.

The interview contains a number of questions or statements that ask the respondent to answer or respond to. The contents of the questions or statements in the interview include facts, data, knowledge, concepts, opinions, perceptions or evaluations of the 
respondents regarding the focus of the problem or the variables studied in the study. Interviews were conducted with lecturers and several active students who took online lectures on the Salesmanship course. The interview paradigm used was semi-structured interviews. This semi-structured paradigmatic is used with considerations more flexible than the structured and unstructured interview paradigm. The paradigmatic semistructured interview is not too literary nor too far from the sentence that has been prepared, and the interview continues in a directed manner.

Documentary study is a data collection technique by collecting and analyzing documents, in this study the documents used include SEMESTER LESSON PLAN, Assessment, Attendance, Question text, and others. Primary data (Primary Source) in this study were obtained through observation and interviews with students and lecturers of the Surabaya State University of Commerce Education study program related to the application of online learning in the midst of the COVID-19 pandemic. Meanwhile, secondary data in this study were obtained from books, encyclopedias, articles, journals, or other writings related to research.

\section{Data Analysis}

The data analysis used by the writer is descriptive analysis which describes the actual situation which is considered accurate, then translates it into the context of writing scientific papers by feeling, explaining, describing, classifying, and interpreting the collected data as is first. When all the data has been collected, the data is sorted according to the existing theme, then the data unit processing is carried out which then becomes the unit typology. From this stage, a separate piece of information will be formed (unit of information). The next step is to define or define categories, finally interpret the data and draw conclusions by making a logical narrative.

Data triangulation is also a technique to check the validity of the data. Triangulation of data in this study tried to double-check the sources and methods. Checking the data includes: 1) comparing observed data with interview data 2) comparing what has been applied with existing theories 3) comparing a person's situation or perspective with various opinions. Also included in the data validity checking technique is peer examination through discussion and adequacy of references.

\section{RESULTS AND DISCUSSION}

Learning objectives are a specific statement expressed in behavior or appearance which is manifested in writing to describe the expected learning outcomes. This behavior can be in the form of concrete and visible facts and vague facts (Hamzah; 2008). The results of the Lecturer Interview Data show the lecturers' plans to carry out online learning in salesmanship courses in the midst of the COVID-19 pandemic starting from the semester lesson plan, the materials, the media used are the assessment method, assignments and final exams. The second lecturer said modules, media, semester lesson plan, assessments, assignments, final examinations were his attributes. The results of the material presented by the lecturer in online learning are arranged the same as the semester lesson plan, only with different media, in general they are almost the same, but we have to think again about how the practice should be controlled. Michael (2013) shows that planning the right media selection and application is needed in online learning. The 2tors.com online tutoring application is still very simple, only based on the use of html, xml, and $\mathrm{ftp}$, so that the interaction that occurs is still very minimal. So 
we need a more interactive application based on the use of PHP and MySql as the database.

The application of online learning demands the readiness of various parties, both from education service providers or from students themselves (Susanty, 2020). The chosen online learning media must be easily accessible to students with a minimum quota and guaranteed continuity. Because it cannot be denied that there are some students who experience problems in terms of smooth access. Then for learning media there are modules and videos, this is adjusted to the learning objectives at semester lesson plan. Online learning is not something new for universities, because many universities have innovated and developed online learning to improve its quality and quality (Hutauruk, 2020).

The Open University uses three types of e-learning applications, namely the provision of web-based supplement teaching materials known as web-supplements, web-based tutorials known as electronic tutorials (tutel), and online courses (web-based courses) (Belawati, 2013). For media in terms of online learning intermediaries, I prefer the WhatsApp application and also the Google class, because the features are simpler and easier to understand and also easy to access. For learning media, I use modules and videos, sometimes with voice notes when there are discussions in the Whatsapp group.

From the first lecturer's answer, the assessment will be adjusted to the activeness and process of conducting discussions, assignments and final exam scores. In general, the assessment process is not much different from face-to-face learning. The second lecturer said that the assessment used was the same as the face-to-face evaluation process, including participation assessment, assignment assessment, final examinations, and midterm examinations. Adamrial (2015) implementation of learning through electronic media can improve the process of implementing learning, it can be seen from the results of student tests that can achieve scores of all students above the Minimum Completeness Criteria.

Regarding the obstacles faced and how to overcome the obstacles that exist in online learning planning, both said that there were a number of students who had difficulty attending lectures due to bad signals and also the difficulty of monitoring anyone who was active in online learning due to media limitations. It turns out that the 2tors.com online tutoring application is still very simple, only based on the use of html, xml, and $\mathrm{ftp}$, so that the interaction that occurs is still very minimal. So we need a more interactive application based on the use of PHP and MySql as the database (Hanum, 2013). How to deal with attendance at the end of the session and also the learning process is carried out with easily accessible media such as Whatsapp where all students have accounts and applications.

Regarding the implementation, they said carelessly, because this online learning position was impromptu, they were trying their best to prepare all media to teaching materials, they still need to learn a lot about distance education systems like this. Another lecturer said that implementation was made simple but according to the portion where in distance learning or online learning there were still many things that needed to be addressed and when learning took place on the official website of Vlearn Unesa it was difficult. The applications they use in the online learning process are ZOOM, Google Meet, Whatsapp, Google Classroom (Mulyiadi, 2021). Regarding forms of supervision in online learning, it is usually carried out by checking attendance at the end because if attendance is done at the beginning, many students will only be present 
briefly later when the learning takes place they will leave. participating in online learning was good enough but they complained about the large number of tasks given with short grace periods. Moreover, supervision in the learning process is rather loose so it is prone to skipping, the learning process is sometimes interrupted by the network, constraints in assigning assignments replace field practice.

Hanum, (2013) Regarding evaluation in formative form, it is an assignment and is collected directly. In accordance with the results of observations, the researcher gives a task to summarize or even gives a quiz or project. The summative evaluation is the midterm and final exams. The percentage of student learning outcomes assessments ranging from formative, summative, and active in online learning in accordance with UNESA policies and there are additional assignments or improvements if student learning outcomes are less than standard scores (Rusly, 2021). The biggest challenge comes especially in the salesmanship course, where this course must produce a skill that is directly assessed but becomes difficult when a pandemic occurs. From the Student Interview data, it was said that all lecturers were very clear in providing online lecture planning, especially at the beginning of the meeting the lecturer always explained the learning process to be carried out as the final goal. All students know the semester lesson plan because they can download at Siakadu the UNESA academic system. All students said that the lecturer explained the plan for online lecture activities, and made it easier for them to understand lectures. About Modules and Videos all are semester lesson PLAN compliant.

Network problems sometimes make the class take longer than usual because the process sometimes we cannot interface, other students say network constraints are sometimes too heavy and large, especially video quota which is quite a lot (Hautauruk, 2020). Regarding the implementation of online lectures in the distance education system which is carried out in the Salesmanship course, the majority of students said that at first it was quite fun but on certain materials that should be done direct practice was not optimal, said another. quite fun sharing videos which are also interesting but the task is piling up, they also think that online lectures are easily accessible even though sometimes the network is unpredictable.

The media used by lecturers in online lectures are videos, modules, PPT, and they agree that the media is easy to access and understand, but they feel that the media is not interesting and innovative. reveals some of the factors that can create an engaging learning experience for online learners are creating and maintaining a positive learning environment, building learning communities, providing consistent feedback in a timely manner, and using the right technology to deliver the right content. This is understood by the lecturers, but due to the sudden implementation of online learning due to the pandemic, media preparation for the implementation of online learning has become less than optimal (Susanty, 2020).

About what the difference felt between online lectures and face-to-face lectures, their answer was that online lectures collected assignments, but could be done anytime and anywhere and online lectures were simpler (Hatauruk, 2020). The following are the results of the questionnaire responses in the study. 
Table 1. Questionnaire result.

Responds Results

\begin{tabular}{|c|c|c|c|c|c|}
\hline Statements & 1 & 2 & 3 & 4 & 5 \\
\hline The media are easily accessed & & & $15 \%$ & $35 \%$ & $50 \%$ \\
\hline I feel that I can learn more by using the media provided & & & $10 \%$ & $80 \%$ & $10 \%$ \\
\hline I feel that the videos and modules ICT more interest & & & & $15 \%$ & $85 \%$ \\
\hline I feel the choice of language used is easily to understand & & & & $20 \%$ & $80 \%$ \\
\hline $\begin{array}{l}\text { I find it airier to understand the material after studying with the } \\
\text { module and video media }\end{array}$ & & & & $25 \%$ & $75 \%$ \\
\hline $\begin{array}{l}\text { I feel that tbe video and module have the right and compatible } \\
\text { combination of colors and graphics }\end{array}$ & & & & $30 \%$ & $70 \%$ \\
\hline I feel the contents in the module and. Video are consistent & & & & $23 \%$ & $77 \%$ \\
\hline
\end{tabular}

From the results of the discussion response questionnaire, it shows that the more answers that lead to agreeing answers become strongly agree, it can be concluded that most students give positive responses to learning media. In addition to a questionnaire about which material was the student's favorite in learning during the pandemic, it was technical material selling online which was effective, where students rated material on the topic as very relevant to the current situation.

\section{CONCLUSIONS}

From the above discussion, the following conclusions can be drawn: The results showed that the learning tools in the form of salesmanship modules and videos received a very high response, and were effective in fostering student interest in learning. The results of the student response data analysis showed that salesmanship modules and videos made learning easier and more enjoyable. Regarding the topic of effective techniques to sell online during a pandemic, it is very relevant to today's needs. Where the material also received a good response and became the student's favorite material. who took the Salesmanship class. Online implementation during the pandemic is new, but the lecturers still consistently adhere to face-to-face procedures where lecturers still adapt the material to the lesson plan semester, mentoring when participants do online activities, provide introductory material and are also creative. suitability of final and midterm examinations. Suggestions for further research are to add several learning methods, as well as to add several other, more measurable variables. It is also possible to add data that can be processed into quantitative data so that it can better present the results. Limitation in this research is related to curriculum changes in subject matter that will be delivered to students and subjects outside of marketing.

\section{REFERENCES}

Admiraal, W., Huisman, B., \& Pilli, O. (2015). Assessment in massive open online courses. Electronic Journal of E-learning, 13(4), 207-216.

Atsani, K. L. G. M. Z. (2020). Transformasi media pembelajaran pada masa Pandemi COVID19. Al-Hikmah: Jurnal Studi Islam, 1(1), 82-93.

B. Uno, Hamzah. 2008. Perencanaan Pembelajaran. Jakarta: Bumi Aksara. Damayati dan mudjiono. 2006. Belajar dan pembelajaran. Jakarta: PT. Rineka Cipta.

Belawati, T. (2013). Penerapan e-learning dalam pendidikan jarak jauh di Indonesia. Cakrawala Pendidikan: E-learning, 10(1), 398-418.

Gaebel, Michael. 2013. MOOCs Massive Open Online Course. Belgium: Ueropean University Association Occasional papers. 
Hanum, N. S. (2013). Keefetifan e-learning sebagai media pembelajaran (studi evaluasi model pembelajaran e-learning SMK Telkom Sandhy Putra Purwokerto). Jurnal Pendidikan Vokasi, 3(1), 34-48.

Hutauruk, A. J. (2020). Kendala pembelajaran daring selama masa pandemi di kalangan mahasiswa pendidikan matematika: Kajian kualiatatif deskriptif. Sepren, 2(1), 45-45.

Joharudin, A., Septiadi, M. A., Maharani, S., Aisi, T. D., \& Nurwahyuningsih, N. (2020). Panic Syndrom Covid-19: Penekanan Terhadap Kebijakan Yang Diberikan. Jurnal Perspektif, 4(1), 44-53.

Muliadi, A., Mirawati, B., \& Jannah, H. (2021). Efektivitas Pembelajaran Daring di Masa Pandemi Covid-19: Persepsi Mahasiswa Pendidikan Biologi. JISIP (Jurnal Ilmu Sosial dan Pendidikan), 5(2), 111-123.

Pakpahan, R., \& Fitriani, Y. (2020). Analisa pemanfaatan teknologi informasi dalam pembelajaran jarak jauh di tengah pandemi virus corona Covid-19. Journal of Information System, Applied, Management, Accounting and Research, 4(2), 30-36.

Rusly, R. A., \& Sudarwanto, T. (2021). Pengaruh praktek mata kuliah Salesmanship terhadap kompetensi mahasiswa (studi kasus mahasiswa S1 Pendidikan Tata Niaga UNESA). Jurnal Pendidikan Tata Niaga (JPTN), 9(2), 52-67.

Sumarni, Y. (2020). Pandemi Covid-19: Tantangan Ekonomi dan Bisnis. Al-Intaj: Jurnal Ekonomi dan Perbankan Syariah, 6(2), 46-58.

Susanty, S. (2020). Inovasi pembelajaran daring dalam merdeka belajar. Jurnal Ilmiah Hospitality, 9(2), 157-166.

\section{Harti}

Business Education, State University of Surabaya, Surabaya, Indonesia

Jl. Ketintang No.2, Ketintang, Kec. Gayungan, Surabaya City, 60231 East Java, Indonesia

Email: harti@unesa.ac.id

* Raya Sulistyowati (Corresponding Author)

Business Education, State University of Surabaya, Surabaya, Indonesia

J1. Ketintang No.2, Ketintang, Kec. Gayungan, Surabaya City, 60231 East Java, Indonesia

Email: rayasulistyowati@unesa.ac.id

\section{Tri Sudarwanto}

Business Education, State University of Surabaya, Surabaya, Indonesia

Jl. Ketintang No.2, Ketintang, Kec. Gayungan, Surabaya City, 60231 East Java, Indonesia

Email: trisudarwanto@,unesa.ac.id

\section{Septyan Budi Cahya}

Business Education, State University of Surabaya, Surabaya, Indonesia

Jl. Ketintang No.2, Ketintang, Kec. Gayungan, Surabaya City, 60231 East Java, Indonesia

Email: septyancahya@unesa.ac.id

\section{Veni Rafida}

Business Education, State University of Surabaya, Surabaya, Indonesia

J1. Ketintang No.2, Ketintang, Kec. Gayungan, Surabaya City, 60231 East Java, Indonesia

Email: venirafida@unesa.ac.id

\section{Tareq Furas}

Master Of Economic, University Putra Malaysia, Malaysia

JALAN UNIVERSITI 1 Serdang, 43400 Seri Kembangan, Selangor, Malaysia

Email: tareqfuras@upm.edu.my 